Bayero Journal of Pure and Applied Sciences, 11(1): 490 - 496

ISSN 2006 - 6996

\title{
SELECTED MINERAL AND ANTI-NUTRIENT COMPOSITION OF THREE VARIETIES OF Hibiscus sabdariffa Linn (ROSELLE) CALYCES
}

\author{
${ }^{1}$ Yakubu, Y., ${ }^{1}$ Hannatu, A. S. and ${ }^{*}{ }^{2}$ Garba, A. \\ ${ }^{1}$ Department of Pure and Appied Chemistry, Kebbi State University of Science and \\ Technology Aliero, Nigeria. \\ ${ }^{2}$ Department of Animal Science, Faculty of Agriculture, Usmanu Danfodiyo University \\ Sokoto, Nigeria. \\ *Corresponding Author: grbabdullahi70@gmail.com
}

\section{ABSTRACT}

The mineral and anti-nutrient composition of Hibiscuss sabdariffa linn calyces of dark red, red and white varieties from three sites in Zuru, Kebbi State, Nigeria. The sun dried samples were analysed for proximate, mineral, anti-nutrient and ascorbic acid. $\mathrm{Ca}, \mathrm{Mg}, \mathrm{Fe}, \mathrm{Cu}, \mathrm{Mn}$ and $\mathrm{Zn}$ were analysed using AAS, while flame photometer was used for $K$ and $\mathrm{Na}$. $\mathrm{P}$ was determined by the vanadomolybdadate method and ascorbic acid by spectrophotometric method. Phytic acid, oxalate and nitrate were determined using titration method. Saponin and cyanogenic glycoside were determined by gravimetric and spectrophotometric methods respectively. Only the concentrations for $\mathrm{Ca}$ and $\mathrm{Mg}$ (among the macro elements) showed no significant difference $(p<0.05)$ among the three varieties. Only the concentrations for Fe and $\mathrm{Cu}$ (among the micro elements) showed no significant difference $(p<0.05)$. The concentrations for ascorbic acid also showed no significant difference $(p<0.05)$. Similarly, the concentrations for Phytate and saponins showed no significant difference $(p<0.05)$. Therefore, there is no much difference in the choice of dark red, red or white calyces of $H$. sabdariffa collected from Zuru for the purpose of supplying to the body $\mathrm{Mg}, \mathrm{Ca}, \mathrm{Fe}, \mathrm{Cu}$ and Ascorbic acid.

Keywords: mineral, anti-nutrient, dark red, red and white, roselle, calyces,

\section{INTRODUCTION}

Traditional African vegetables are extremely important for nutrition and are source of farm income, as they often supply most of the daily requirements for proteins, minerals and vitamins to the poor rural people (Okafor, 1995. It has been reported that nutrient deficiency diseases such as night blindness, scurvy and rickets common among Africans, can be avoided by greater consumption of nutritious vegetables (Mnzava, 1997). Hibiscus sabdariffa linn commonly called roselle is an annual erect, bushy herbaceous sub shrub with smooth or nearly smooth, cylindrical red stem. The plant is widely grown in the North and middle belt regions of Nigeria probably because of the climate (Babalola et al., 2001). The plant has been found to thrive on a wide range of soil conditions. It can perform satisfactorily on relatively infertile soils but for economic purposes, a soil well supplied with organic materials and essential nutrients is required (Adanlawo and Ajibade, 2006). It can tolerate relatively high temperature throughout the growing and fruiting periods. The plant requires an optimum rainfall of approximately $45-50 \mathrm{~cm}^{3}$ distributed over a 90-120 days growing period (Amin et al., 2008). The plant is gaining wide acceptance, being consumed by several millions of people from different socio-economic classes and background in the West African sub-region, especially amongst the youths, who sees zobo drink as an alternative source of cheap and relaxing non-alcoholic drink in social gathering. It also, served as resources of food, medicine, food supplement, fibre and other organic compounds (Ogiehor and Nwafor, 2004).

The nutrients composition of $H$. sabdariffa leaves, seeds and calyces being the exploited parts varies between studies, probably due to difference in variety, genetic, environmental, ecology and harvest conditions of the plant (Atta et al., 2013). The most exploited part of a roselle plant is the calyces, which are obtained by removing the calyces or petals of the flower from its capsules containing the seeds. Calyces are used for the preparation of herbal drink, cold and warm beverages, jams and jellies (Tsai et al., 2002). The calyces of $H$. sabdarifta have been reported to be rich in Vitamins, natural carbohydrate, protein and Vitamin $\mathrm{C}$ and other antioxidants and also minerals, which constitute the major reason(s) for consuming soft drink and fruit juiced (Olayemi e $t$ al., 2011). The roselle calyces are reported to be nutritious, although they also contained anti-nutritional factors, that are naturally found, such as phytic acid, saponin, oxalic acid, tannin, nitrate, which interfere with the absorption of vitamins, minerals and other nutrients. 
However, some of these anti-nutritional compounds have benefits as opposed to mostly harmful effects, as some are reported to be anti-cancer agents (Adanlawo and Ajibade, 2006). Adanlawo and Ajibade (2006) reported the presence of $\mathrm{Na}, \mathrm{K}, \mathrm{Mg}, \mathrm{P}$ and $\mathrm{Ca}$ (macro elements) and $\mathrm{Fe}, \mathrm{Cu}, \mathrm{Zn}, \mathrm{Mn}$ and $\mathrm{Ni}$ (micro elements) in red and green calyces of $H$ sabdariffa and observed $\mathrm{K}$ to be the most abundant. They also reported the presence of very low levels of phytic acid, oxalate, tannic acid and hydrocyanic acid. Babalola et al., (2001) observed in high concentration the presence of $\mathrm{Ca}, \mathrm{Mg}$, and $\mathrm{Zn}$ in the dark red calyx but did not varied significantly with that of the red colour type. Shrawan et al., (2013) observed the presence of nitrate, phytate, oxalate and saponin in the mature and immature seeds, flower, fruit, calyx and leaf of $H$. sabdariffa. The highest concentrations for nitrate and oxalate were in the calyx, while for phytate and saponin were in the flower and fruit respectively. This study was aimed to investigate the mineral, ascorbic acid and antinutrients composition of three varieties of $H$. sabdarifta calyces ( red, dark red and white) with a view to provide data for dietary planning.

\section{MATERIAL AND METHODS \\ Sampling site}

The samples were obtained from Zuru Local Government Area of Kebbi State. Zuru is one of the twenty one (21) local government areas of Kebbi State. It is located within latitudes $11^{\circ} 35^{\prime}$ to $11^{\circ} 55^{\prime} \mathrm{N}$ and longitudes $4^{\circ} 45^{\prime}$ to $5^{\circ} 25^{\prime} \mathrm{E}$ of the equator, at the extreme south eastern part of Kebbi State and covers an area of approximately 32, 626 square kilometer. (Kebbi State Government, 2003).

Sample Collection and Preparation

A $600 \mathrm{~g}(200 \mathrm{~g} \times 3)$ of fresh calyces for each of the three varieties of $H$. sabdariffa cultivated by the local farmers were collected randomly from three agricultural fields in Gwammawa, Rikoto and Zanga sites, in Zuru, Kebbi State, Nigeria. The collections made in the months of October and November, 2017, when calyces were fully matured and ready for harvest. After cleaning by removing visually observed noncalyces matter, the calyces for each of the varieties were sun dried for a period of two weeks. The dried samples were then crushed into fine powder before storing in clean and clearly labeled polythene bags. The powdered samples were used in all the analyses (Hassan et al, 2008; Miroslav and Vladimir, 1999).

Proximate Analyses

The proximate analyses of the $H$. sabdariffa calyces were determined according to AOAC
(2005). The moisture content was determined by drying in oven (SM 9053 Uniscope, England) at $105^{\circ} \mathrm{C}$ until a constant weight was obtained. Ash was determined by weighing the incinerated residue obtained in a furnace (Lenton Furnace SN 4422, England) at $600^{\circ} \mathrm{C}$ for 3 hrs. Total crude protein content was determined using the Kjeldahl method (kjeltec 2100, Foss, Sweden) and percentage crude protein was calculated as $\% \mathrm{~N}_{2}$ (Nitrogen) $x$ 6.25. The total lipid in the samples was determined by Soxhlet method. The available carbohydrate was estimated using anthrone reagent method as described by (Kumar et al., 2012).

\section{Mineral Analyses}

The samples were digested using dry digestion method by taking $2.0 \mathrm{~g}$ of each in a crucible and placed into a muffle furnace at $600^{\circ} \mathrm{C}$ for three hours. After cooling ten milliliters of 5.0 $\mathrm{N} \mathrm{HCl}$ was then added to the ash and dissolved it, then filtered the mixture into a $50 \mathrm{~cm}^{3}$ volumetric flask. The volume was made to the mark with distilled water and the digest was used directly for the elemental determination. $\mathrm{Ca}, \mathrm{Mg}, \mathrm{Fe}, \mathrm{Cu}, \mathrm{Zn}$ and $\mathrm{Mn}$ were determined using Atomic Absorption Spectrophotometer (AA 6300 Shimadzu Model, England). Flame photometer (Model 400, Corning U.K.) was used for $\mathrm{K}$ and $\mathrm{Na}$ determination, while phosphorous was determined by the vanodo-molybdate method using spectrophotometer (optima sp300 model) at $660 \mathrm{~nm}$ according to the method described by AOAC (2005).

\section{Ascorbic Acid Analysis}

The ascorbic acid (vitamin C) content of the samples was determined spectrophotometry (optima sp- 300 model) at $660 \mathrm{~nm}$ according to Rutkowski and Grzegorczyk (2007) method.

\section{Anti-nutritive Analyses}

The Anti-nutrients which include. phytate, nitrate, cyanogenic glycoside, saponin and oxalate were estimated in the three different varieties of $H$. Sabdariffa calyces. The phytic acid, oxalate and nitrate content were determined using titration method as described by Hassan et al., (2008). The saponin content was determined using gravimetric methods and cyanogenic glycoside content was determined using spectrophotometric method as described by AOAC (2005).

\section{Statistical Analysis}

The data obtained from the analyses were subjected to analyses of variance (ANOVA) and were expressed as Mean \pm standard deviation of triplicate analyses. All data were analysed using the startview statistical package (SAS, 2002). A p-value of $<0.05$ was considered as statistically significant between mean values. 


\section{RESULTS AND DISCUSSION}

The results of the proximate, mineral, vitamin $\mathrm{C}$ and anti-nutritive composition of the three varieties of $H$. sabdariffa (roselle) calyces are presented in Tables $3.1, \quad 3.2$ and 3.3 respectively.

\section{Proximate Composition}

The results of the mean proximate composition of the three varieties of $\mathrm{H}$. sabdariffa calyces are presented in Table 1 . The varieties had mean protein content ranged from 7.70 to 9.86 $\%$, fibre from 9.33 to $11.0 \%$, available carbohydrate from 22.67 to $37.67 \%$, lipid from 2.07 to $2.36 \%$, ash from 5.50 to $9.50 \%$ and moisture from 8.00 to $8.83 \%$. There were significant differences $(p<0.05)$ in the mean values of protein, fibre and available carbohydrate among the three varieties of $H$. sabdariffa.

Minerals composition

The results of the mean minerals composition of the three varieties of $H$. sabdariffa calyces are presented in Table 2 in $\mathrm{mg} / 100 \mathrm{~g}$. The varieties had mean $\mathrm{Na}$ content ranged from 3.63 to 4.20 , $\mathrm{K}$ from 117.00 to 133.33 , Ca from
91.04 to $208.46, \mathrm{Mg}$ from 199.49 to $203.68, \mathrm{P}$ from 4.10 to 4.30 , Fe from 2.06 to $2.27, \mathrm{Zn}$ from 1. 75 to 3.56 and $\mathrm{Mn}$ from 3.42 to 5.31 . There were significant differences $(p<0.05)$ in the mean values of $\mathrm{Na}, \mathrm{K}, \mathrm{P}, \mathrm{Zn}$ and $\mathrm{Mn}$ among the three varieties. The difference was observed between dark red and red for $\mathrm{Na}$, dark red and white as well as red and white for K. Similarly, the difference was observed between dark red and white as well as dark red and red for $\mathrm{Zn}$ and $\mathrm{Mn}$. For $\mathrm{P}$, the difference was observed between the red and white.

Anti-Nutrients and Ascorbic acid Composition The results of the mean antinutrients composition of the three varieties of $\mathrm{H}$. sabdariffa calyces are presented in Table 3 in $\mathrm{mg} / 100 \mathrm{~g}$. The varieties had mean Cyanogenic glycoside content ranged from 147.44 to 355.88 , nitrate from 27.50 to 51.00 , oxalate from 180.00 to 405.00 , phytate from 1.41 to 2.28 , saponin from 7.33 to 7.67 and ascorbic acid from 77.13 to 108.66 . There were no significant differences $(p<0.05)$ in the mean values of phytate, saponin and ascorbic acid among the three varieties.

Table 1: Proximate Composition of the three varieties of $H$. sabdariffa calyces in percentage (\%) sun dry basis

\begin{tabular}{llll}
\hline & \multicolumn{3}{l}{ Calyx types } \\
\cline { 2 - 4 } Parameter & Dark red & Red & White \\
\hline Moisture & $8.33 \pm 2.47^{\mathrm{a}}$ & $8.00 \pm 1.32^{\mathrm{a}}$ & $8.83 \pm 2.93^{\mathrm{a}}$ \\
Ash & $6.83 \pm 2.02^{\mathrm{a}}$ & $5.50 \pm 0.50^{\mathrm{a}}$ & $9.50 \pm 2.65^{\mathrm{b}}$ \\
Crude Lipid & $2.36 \pm 0.31^{\mathrm{a}}$ & $2.33 \pm 0.29^{\mathrm{a}}$ & $2.07 \pm 0.40^{\mathrm{a}}$ \\
Crude Fibre & $9.33 \pm 0.29^{\mathrm{a}}$ & $11.00 \pm 0.87^{\mathrm{b}}$ & $10.33 \pm 0.58^{\mathrm{ab}}$ \\
Crude Protein & $9.86 \pm 0.20^{\mathrm{a}}$ & $7.70 \pm 0.18^{\mathrm{b}}$ & $9.63 \pm 0.76^{\mathrm{a}}$ \\
Available Carbohydrate & $37.67 \pm 0.58^{\mathrm{a}}$ & $22.67 \pm 0.58^{\mathrm{b}}$ & $33.67 \pm 1.53^{\mathrm{c}}$ \\
CaloricficValue (kcal/100g) & $211.12 \pm 3.01^{\mathrm{a}}$ & $142.48 \pm 3.12^{\mathrm{b}}$ & $191.71 \pm 6.05^{\mathrm{c}}$ \\
\hline
\end{tabular}

Data reported as Mean \pm SD. Means followed by different letters $(a-c)$ in the same row are significantly different

from each other $(p<0.05)$. Values are means \pm standard deviations of triplicate determination.

Table 2: Macro and Micro Minerals composition of the three varieties of $\boldsymbol{H}$. sabdariffa calyces in $\mathrm{mg} / 100 \mathrm{~g}$ sun dry basis

\begin{tabular}{llll}
\hline & \multicolumn{3}{c}{ Calyx types } \\
\cline { 2 - 4 } Mineral Element & Dark red & Red & White \\
\hline Sodium (Na) & $4.20 \pm 0.17^{\mathrm{a}}$ & $3.73 \pm 0.12^{\mathrm{b}}$ & $3.63 \pm 0.57^{\mathrm{ab}}$ \\
Potassium (K) & $133.33 \pm 2.89^{\mathrm{a}}$ & $131.67 \pm 2.89^{\mathrm{a}}$ & $117.00 \pm 2.65^{\mathrm{b}}$ \\
Calcium(Ca) & $91.04 \pm 21.56^{\mathrm{a}}$ & $208.46 \pm 30.16^{\mathrm{b}}$ & $129.85 \pm 39.74^{\mathrm{ac}}$ \\
Magnesium (Mg) & $201.20+4.48^{\mathrm{a}}$ & $203.68 \pm 7.85^{\mathrm{a}}$ & $199.49 \pm 2.64^{\mathrm{a}}$ \\
Phosphorus (P) & $4.17 \pm 0.10^{\mathrm{a}}$ & $4.10 \pm 0.08^{\mathrm{b}}$ & $4.30 \pm 0.10^{\mathrm{c}}$ \\
Iron (Fe) & $2.27 \pm 0.72^{\mathrm{a}}$ & $2.06 \pm 1.04^{\mathrm{a}}$ & $2.13 \pm 0.32^{\mathrm{a}}$ \\
Copper (Cu) & $0.36 \pm 0.21^{\mathrm{a}}$ & $0.17 \pm 0.10^{\mathrm{a}}$ & $0.20 \pm 0.06^{\mathrm{a}}$ \\
Zinc (Zn) & $3.56 \pm 0.37^{\mathrm{a}}$ & $1.75 \pm 0.50^{\mathrm{b}}$ & $2.30 \pm 0.47^{\mathrm{b}}$ \\
Manganese (Mn) & $5.31 \pm 0.68^{\mathrm{a}}$ & $3.42 \pm 0.50^{\mathrm{b}}$ & $4.09 \pm 0.12^{\mathrm{b}}$ \\
\hline
\end{tabular}

Data reported as Mean \pm SD. Means followed by different letters $(\mathrm{a}-\mathrm{c})$ in the same row are significantly different from each other $(p<0.05)$. Values are means \pm standard deviations of triplicate determination. 
Table 3: Anti-Nutrient and Ascorbic acid Composition of the three varieties of $\mathrm{H}$. sabdariffa linn calyces in $(\mathrm{mg} / 100 \mathrm{~g})$ sun dry basis

\begin{tabular}{llll}
\hline & \multicolumn{3}{l}{ Calyx types } \\
\cline { 2 - 4 } Parameter & Dark red & Red & White \\
\hline Cyanogenic glycoside & $355.88 \pm 61.64^{\mathrm{a}}$ & $147.44 \pm 7.52^{\mathrm{b}}$ & $156.11 \pm 32.52^{\mathrm{b}}$ \\
Nitrate & $51.00 \pm 3.46^{\mathrm{a}}$ & $27.50 \pm 1.73^{\mathrm{b}}$ & $32.33 \pm 6.51^{\mathrm{b}}$ \\
Oxalate & $195.00 \pm 51.96^{\mathrm{a}}$ & $180.00 \pm 45.00^{\mathrm{a}}$ & $405.00 \pm 45.0^{\mathrm{b}}$ \\
Phytate & $2.28 \pm 0.25^{\mathrm{a}}$ & $2.11 \pm 0.25^{\mathrm{a}}$ & $1.41 \pm 0.49^{\mathrm{a}}$ \\
Saponin & $7.33 \pm 1.53^{\mathrm{a}}$ & $7.33 \pm 1.53^{\mathrm{a}}$ & $7.67 \pm 4.04^{\mathrm{a}}$ \\
Ascorbic acid & $77.13 \pm 27.73^{\mathrm{a}}$ & $91.99 \pm 21.56^{\mathrm{a}}$ & $108.66 \pm 13.69^{\mathrm{a}}$ \\
\hline
\end{tabular}

Data reported as Mean \pm SD. Means followed by different letters (a-c) in the same row are significantly different from each other $(p<0.05)$. Values are means \pm standard deviations of triplicate determination.

\section{DISCUSSION \\ Proximate Composition of the three varieties of $H$. sabdariffa calyces}

The values for moisture content were in agreement with the values of $7.60 \%$ and $6.24 \%$ reported by Adanlawo and Ajibade (2006) on red and green calyces respectively and also $9.20 \%$ showed by Shivali and Pradeep (2009). But, lower when compared with the values of $15 \%$ reported by Tee et al., (2002), $11 \%$ in red calyx and $9.30 \%$ in white reported by Adam, (2005) and $12.81 \pm 0.03 \%$ indicated by Azza et al., (2011). The values for the ash content compared well with $6.5-6.8 \%$ previously reported by Babalola et al. (2001) on red, green and dark red roselle calyces, but were lower than the values of $11.24 \pm 0.02 \%$ reported by Azza et al., (2011) and $10.60 \%$ in red and $9.50 \%$ in white by Adam (2005). Since the ash content gives an idea of the inorganic composition of a sample, the observed values indicated that the three varieties may be rich in mineral content.

The crude lipid content were higher than the values of $0.16 \%$ in red and $0.12 \%$ in white calyces reported by Adam, (2005) and $0.46 \pm 0.03 \%$ showed by Azza et al., (2011) on red and white calyces. The fibre contents were found to be in agreement with the results $9.8 \%$ in dark red, $8.5 \%$ in red and $11.2 \%$ in green obtained by Babalola et al., (2001) and $11.17 \pm 0.02 \%$ in red calyx reported by Azza et al., (2011). On the other hand, the values were lower than $13.2 \%$ in red and $12 \%$ in white reported by Shivali and Pradeep (2009), 12\% by Tee et al., (2002) and $13.2 \%$ in red and $12 \%$ in white as reported by Adam, (2005). The crude protein content were within the range of $7.5 \pm 0.02 \%$ reported by Azza et al. (2011) and $9.8 \%$ in dark red, $8.5 \%$ in red and $11.2 \%$ in green by Babalola et al., (2001 which is in agreement with the literature. The available carbohydrate results were inconsistant with the values of $12.3 \%$ reported by Gabb, (1997),
$11.2 \%$, by Atta, (2002), $15 \%$ by Tee et al., (2002) and $57.16 \%$ in red and $61.55 \%$ in white by Adam (2005). This may be as a result of the method of analyses used in this work.

\section{Mineral Composition of $\boldsymbol{H}$. sabdariffa calyces}

The values for $\mathrm{Na}$ were lower when compared with $57.16 \%$ in red and $61.55 \%$ in white reported by Adanlawo and Ajibade (2006), $9.5 \mathrm{mg} / 100 \mathrm{~g}$ in green, $5.5 \mathrm{mg} / 100 \mathrm{~g}$ in red and $6.5 \mathrm{mg} / 100 \mathrm{~g}$ in dark red by Babalola et al., (2001) and $6.62 \pm 0.02 \mathrm{mg} / 100 \mathrm{~g}$ by Azza et al. (2011). Since sodium plays an important role in osmotic regulation of the body fluids and transmission of nerve impulses and is normally required in very small amount, the observed low values makes the calyces of the three varieties suitable as part of antihypertensive diet (McDonald et al., 1995). The values of potassium were higher when compared with $49.35 \mathrm{mg} / 100 \mathrm{~g}$ in red calyx and $49.59 \mathrm{mg} / 100 \mathrm{~g}$ in green reported by Adanlawo and Ajibade (2006) and $20.60 \pm 0.02 \mathrm{mg} / 100 \mathrm{~g}$ in red calyx by Azza et al., (2011). On the other hand, Babalola et al., (2001) reported higher values of $1850 \mathrm{mg} / 100 \mathrm{~g}$ in green calyx, $2060 \mathrm{mg} / 100 \mathrm{~g}$ in red calyx and $2320 \mathrm{mg} / 100 \mathrm{~g}$ in dark red calyx. The low concentration of sodium and the presence of high amount of potassium in the three varieties suggest their safety in term of health risk. The calcium contents were lower when compared with $1209 \mathrm{mg} / 100 \mathrm{~g}$ in green calyx, $1583 \mathrm{mg} / 100 \mathrm{~g}$ in red calyx and 1602 $\mathrm{mg} / 100 \mathrm{~g}$ in dark red calyx as reported by Babalola et al., (2001). However, lower values of $12.65 \mathrm{mg} / 100 \mathrm{~g}$ in red and $21.58 \mathrm{mg} / 100 \mathrm{~g}$ in green calyx were also reported by Adanlawo and Ajibade, (2006) and also, $12.62 \mathrm{mg} / 100 \mathrm{~g}$ by Shivali and Pradeep (2009). Calcium strengthens bones, teeth and maintain proper bone health, $\mathrm{Ca}$ and $\mathrm{Mg}$ are use to achieve proper muscle contraction as well as nerves function (McDonald et al., 1995). 
Special Conference Edition, November, 2018

The values for magnesium contents were higher when compared with the values of $38.65 \mathrm{mg} / 100 \mathrm{~g}$ in red calyx and $47.54 \mathrm{mg} / 100 \mathrm{~g}$ in green reported by Adanlawo and Ajibade, (2006), but were lower when compared with the values of $315.21 \pm 1.0 \mathrm{mg} / 100 \mathrm{~g}$ in red calyx reported by Azza et al. (2011) and $235 \mathrm{mg} / 100 \mathrm{~g}$ in green, $316 \mathrm{mg} / 100 \mathrm{~g}$ in red and $340 \mathrm{mg} / 100 \mathrm{~g}$ in dark red by Babalola et al., (2001). Mg plays fundamental roles in most reactions involving phosphate transfer, believed to be essential in the structural stability of nucleic acid and intestinal absorption while its deficiency is responsible for severe diarrhea, hypertension and stroke (Onibon et al., 2007). The observed values indicate that the calyces of the three varieties of $H$. sabdariffa could be good source for $\mathrm{Mg}$. The values for phosphorus content were lower than $36.22 \pm 1.0 \mathrm{mg} / 100 \mathrm{~g}$ in red calyx reported by Azza et al., (2011), 273.2mg/100g by Shivali and Pradeep, (2009) and $36.60 \mathrm{mg} / 100 \mathrm{~g}$ in red and $15.05 \mathrm{mg} / 100 \mathrm{~g}$ in green by Adanlawo and Ajibade (2006). Phosphorus is responsible for cell division, reproduction and the transmission of hereditary traits (Adeyeye, 2002). Phosphorus is related to calcium for bones, teeth and muscles growth and maintenance (Umar et al., 2007).

The concentrations of the micro mineral (Fe, $\mathrm{Cu}, \mathrm{Zn}$ and $\mathrm{Mn}$ ) composition in the calyces of the three varieties of $H$. sabdariffa expressed in $\mathrm{mg} / 100 \mathrm{~g}$ are also contained in Table 3.2. The values for $\mathrm{Fe}$ closely relate with the $3.22 \mathrm{mg} / 100 \mathrm{~g}$ in red and $3.37 \mathrm{mg} / 100 \mathrm{~g}$ in green calyx reported by Adanlawo and Ajibade,( 2006), but lower than $37.80 \pm 1.0$ in red calyx reported by Azza et al. (2011) in red calyx and $32.8 \mathrm{mg} / 100 \mathrm{~g}$ in green, $37.8 \mathrm{mg} / 100 \mathrm{~g}$ in red and $34.6 \mathrm{mg} / 100 \mathrm{~g}$ in dark red calyces by Babalola et al., (2001). Iron is an important element in the diet of pregnant women, nursing mothers and infants; it is known that adequate iron in a diet is very important in order to decrease the incidence of anaemia (Oluyemi et al., (2006). Therefore, the calyces of roselle could be a good source of iron. The copper contents were lower when compared with the value of $4.32 \pm 0.03 \mathrm{mg} / 100 \mathrm{~g}$ reported in red calyx by Azza et al., (2011) and $0.70 \mathrm{mg} / 100 \mathrm{~g}$ in red and $0.78 \mathrm{mg} / 100 \mathrm{~g}$ in yellow calyx by Nnam and Onyeke, (2003). However, Adanlawo and Ajibade (2006) reported the absence of $\mathrm{Cu}$ in their work. Deficiency of copper causes cardiovascular disorders as well as anaemia and disorders of the bone and nervous systems (Mielcarz et al., 1997).

The values obtained for $\mathrm{Zn}$ in the samples were lower compared with the values of $12.12 \mathrm{mg} / 100 \mathrm{~g}$ for red and $16.28 \mathrm{mg} / 100 \mathrm{~g}$ in green calyx reported by Adanlawo and Ajibade
(2006) for red and green calyces. The differences in the values may be due to soil, genetic factor or harvesting period. The zinc content in the samples implies that roselle calyces could play a major role in normal body development, since zinc is essential element in protein and nucleic acid synthesis (Mielcarz et al., 1997). The values obtained for manganese were in agreement with the $2.39 \mathrm{mg} / 100 \mathrm{~g}$ in red calyx and $5.61 \mathrm{mg} / 100 \mathrm{~g}$ in green reported by Adanlawo and Ajibade (2006) and $.39 \pm 0.03 \mathrm{mg} / 100 \mathrm{~g}$ in red calyx by Azza, et al., (2011).

\section{Anti-Nutrient Composition of $H$. sabdariffa calyces}

The cyanogenic glycoside (hydrocyanic acid) contents were higher when compared with the values of $132 \mathrm{mg} / 100 \mathrm{~g}$ reported by Okereke et al., (2015) and $0.16 \mathrm{mg} / 100 \mathrm{~g}$ in red calyx and $0.13 \mathrm{mg} / 100 \mathrm{~g}$ in green by Adanlawo and Ajibade (2006). The values for the nitrate contents were lower when compared with the value of $89.34 \mathrm{mg} / 100 \mathrm{~g}$ in calyx and $64.28 \mathrm{mg} / 100 \mathrm{~g}$ in roselle leaf reported by Shrawan et al., (2013). The values were adequate to provide the recommended daily intake level of $3.7 \mathrm{mg} / \mathrm{kg}$ body weight equivalent to $220 \mathrm{mg}$ for $60 \mathrm{~kg}$ person. Nitrate as source nitrous oxide, an important molecule for functioning of muscle cells (Hassan, et al., 2011).

The values of oxalate were lower when compared with the $6150 \mathrm{mg} / 100 \mathrm{~g}$ in red calyx and $6050 \mathrm{mg} / 100 \mathrm{~g}$ in green reported by Adanlawo and Ajibade (2006). However, the results obtained were found to be high compared with $4.39 \mathrm{mg} / 100 \mathrm{~g}$ in calyx and $3.16 \mathrm{mg} / 100 \mathrm{~g}$ in roselle leaf reported by Shrawan et al., (2013). The values for the phytate (phytic acid) contents were lower when compared with the values of $174.81 \mathrm{mg} / 100 \mathrm{~g}$ in calyx and $175.23 \mathrm{mg} / 100 \mathrm{~g}$ in roselle leaf reported by Shrawan et al., (2013, 0.32\% $(320 \mathrm{mg} / 100 \mathrm{~g})$ in red calyx and $1.13 \%$ $(1130 \mathrm{mg} / 100 \mathrm{~g}$ in green Adanlawo and Ajibade (2006) and $1.16 \mathrm{mg} / \mathrm{g}$ by ljeoma et al., (2012). Phytate in the white calyx was lower than in the dark red and red calyx (Table 3. 3).

Since phytate and oxalate are known to decrease the bioavailability of minerals, such as calcium, magnesium, iron and zinc by chelating with them to form strong binding affinities, and thus significantly reducing their bioavailability (Hassan et al., 2011).

The calculated molar ratios of [oxalate] / [Ca] and [oxalate] / [ $\mathrm{Ca}+\mathrm{Mg}]$ of three varieties of roselle calyces were below the critical level of 2.5 , these indicates good bioavailability of $\mathrm{Ca}$ and $\mathrm{Mg}$ due to oxalate (Hassan et al., 2011), 
Special Conference Edition, November, 2018 also, the calculated molar ratios of [Ca] [phytate] / [Zn], [phytate] / [Zn], [phytate] / [Ca] and [phytate] / [Fe] of the three varieties of roselle calyces were below the critical level of $0.5,10,0.2$ and 0.4 respectively and these indicates good bioavailability of $\mathrm{Ca}, \mathrm{Fe}$ and $\mathrm{Zn}$ due to phytate (Hassan et al., 2008, Hassan et al., 2011). The observed values in this work indicated that consumption of the three varieties is not likely to have health risk.

The values for the saponin content were lower when compared with the values $75.00 \mathrm{mg} / 100 \mathrm{~g}$ in calyx and $121.24 \mathrm{mg} / 100 \mathrm{~g}$ in roselle leaf reported by Shrawan et al., (2013) and 0.96\% by Okereke et al., (2015). Since saponin reduced body cholesterol by preventing its reabsorption and cholesterol in the protozoa cell membrane thereby causing it to lyses (Umar et al., 2007).

Vitamin C Composition of $H$. sabdariffa calyces

The vitamin C contents were lower when compared with the values of $139.51 \mathrm{mg} / 100 \mathrm{~g}$ reported by Shrawan et al., (2013), 280$360 \mathrm{mg} / 100 \mathrm{~g}$ by Tee et al., (2002) and $140.13 \pm 3.0 \mathrm{mg} / 100 \mathrm{~g}$ in red calyx by Azza et al., (2011). However, the values were higher when compared with the values of $16.67 \mathrm{mg} / 100 \mathrm{~g}$ in red calyx and $12.50 \mathrm{mg} / 100 \mathrm{~g}$ in green reported by Adanlawo and Ajibade (2006) and $6.70 \mathrm{mg} / 100 \mathrm{~g}$ by Shivali and Pradeep (2009). The differences in the values may be due to genetic factor and harvesting condition. The recommended dietary allowance of vitamin $C$ is $60 \mathrm{mg} /$ day for adults (FAO/WHO, 2001). Based on the results obtained, roselle calyces can supplement the daily vitamin $\mathrm{C}$ requirement.

\section{REFERENCES}

Adam, S. A. 2005. A comparative study on red and white karkade (Hibiscus sabdariffa L.) calyces, extracts and their products. M.Sc. Thesis. Faculty of Engineering and Technology, University of Gezira, Sudan.

Adanlawo, I. G. and Ajibade, V. A. 2006. Nutritive Value of the Two Varieties of Roselle (Hibiscus sabdariffa) Calyces Soaked with Wood Ash. Pakistan Journal of Nutrition 5 (6): 555-557.

Adeyeye, E. I. 2002. Determination of Chemical Composition of the Nutritionaly Valuable parts of Male and Female common West African Fresh Water crab sudananautes Africanus. International journal of Foods Science and Nutrition. 53: 189-196.

Amin, I., Hainida, E. k. and Halimatul, S. M.N. 2008. Roselle (Hibiscus sabdariffa L.) seeds Nutritional composition, protein

\section{CONCLUSION}

This study has shown that, the calyces of the three varieties (dark red, red, and white) of $H$. sabdariffa collected from Zuru contained the selected minerals (macro and micro nutrients), vitamin $\mathrm{C}$ and the anti-nutrient substances. The composition of the macro elements with the exception of $\mathrm{Mg}$ and $\mathrm{Ca}$ in the three varieties indicated significant difference at $p<0.05$, while for the micro elements, only for $\mathrm{Zn}$ and $\mathrm{Mn}$ indicated significant difference. The compositions of the Vitamin C in the three varieties were similar. With the exception of phytate and saponin, the concentrations for the anti-nutrients were not similar. Since the concentrations for oxalate and phytate were below the critical levels, it therefore indicates the bioavailability of the minerals. Therefore, there is no much difference in the choice of dark red, red or white calyces of $H$. sabdariffa collected from Zuru for the purpose of supplying $\mathrm{Mg}, \mathrm{Ca}, \mathrm{Fe}, \mathrm{Cu}$ and Ascorbic acid in the body.

\section{Acknowledgement}

The authors wish to appreciate the efforts of Dr. Muhammad Nasiru and Ahmad Modi of Faculty of Agriculture, Usmanu Danfodiyo University Sokoto, Dr. Ibrahim K Kwaifa of Department of Haematology, School of Medical Laboratory Sciences, Usmanu Danfodiyo University Sokoto and Dr. Ibrahim Garba Wawata of Department of pure and applied chemistry,Kebbi state University of Science and Technology, Aliero, Nigeria.

quality and health benefits. Global science 2 (1): 1-16.

Association of Official Analytical Chemists. 2005. Official method of Analysis of the Association of Officiating Analytical Chemists. Vols I\& II, (18 ${ }^{\text {th }}$ edn $)$. Maryland, USA: 122-135.

Atta, M. B. 2003.Some characteristics of nigella (Nigella sativa L.) seed cultivated in Egypt and its lipid profile. Food chemistry: 83, 63-68.

Azza, A. A., Ferial, M. A. and Esmat, A. A. 2011. Physico- chemical properties of natural pigments (anthocyanin) extracted from Roselle calyces (Hibiscus subdariffa). Journal of American Science 17 (7): 445-456.

Babalola, S.O., Babalola, A.0. and Aworh, O.C. 2001. Compositional attributes of the calyces of roselle (Hibiscus sabdariffa L.). The Journal of Food Technology in Africa, Vol. 6 (4): 133-134. 
FAO/WHO 2001. Expert consultation on human vitamin and mineral requirements. Rome, Italy : 138, 287.

Gabb, S. 1997. Sudanese karkade: A brief introduction, economics file No.12. The Sudan Foundation, London, UK : http//www.sufo.demon.co.Uk/econ012 .htm.

Hassan, L. G.,Dangoggo, S. M., Umar, K. J., Sa,idu, I., and Folorunsho, F. A. 2008. Proximate, Minerals and Antinutritional Factors of Daniellia oliveri Seed kernel. Chemclass Journal, 5: 313

Hassan, L. G,, Umar, K. J., Dangoggo, S. M. and Maigandi, A. S. 2011. Anti-nutrient composition and Bioavailability prediction as exemplified by calcium, iron and zinc in melocia corchorifolia leaves. Pakistan journal of nutrition. 10 (1): 23-28.

Kebbi State Government. 2003. Kebbi State government official diary. Directorate of Infromation, Kebbi, Nigeria: 7-10.

Kumar,V.P., Ch.Madhu, M. K., Asha,V.S., Sambasiva, R and Prasad M. S. 2012: Quantitative evaluation of carbohydrate levels in fruits by UVvisible spectrophotometer. Asian Journal Pharm. Tech., 2 (3): 99-100.

McDonald, P., Edwards, R. A., Greenhalgh, F. D. and Morgan, C. A. 1995. Animal Nutrition. Prentices Hall, London: 90.

Mielcarz, G.W., Howard, A. N., Williams, N.R., Kinsman, G. D., Moriguchi, Y., Mizushima, S. and Yamori, Y. 1997. Copper and Zinc status as a risk factor for Ischemic heart disease: A comparison between Japanese in Brazil and Okinawa. Journal of Trace element experiment of medicine. 10: 29-35.

Miroslav, R. and Vladimir, N.B. 1999. Practical Environmental Analysis. Royal Society Chemistry. U.K: 2, 263-273 and 357 377.

Mnzava, N.A. 1997. Comparing nutritional values of exotic and indigenous vegetables. In African Indigenous Vegetables (Rudy Schippers and Leonard Budd edt). Proceedings of /IPGRI/ International Workshop on African Indigenous Vegetables: 70-75

Ogiehor, I.S. and. Nwafor, O. E. 2004. Associated microbiological, biochemical and chemical quality changes in zobo beverage produced from Hibiscus sadarifa Linn, Niger. Ann. Nat. Sci., 5: 1-10.

Okafor, J.C. 1995. Conservation and use of traditional vegetables from woody forest species in South western Nigeria. In: Traditional African Vegetables (Guarino. L. edt.) Proceedings of (IPGRI) International Workshop 31-38.

Okereke, C. N., Iroka, F. C. and Chukwuma, M. O. 2015. Phytochemical analysis and medicinal uses of Hibiscus sabdariffa. International journal of Herbal medicine. 2 (6): 16-19.

Olayemi, F., Adedayo. R., Muhummad, R. and Bamishaiye, E. 2011. The Nutritional Quality of Three Varieties of Zobo (Hibiscus sabdariffa) Subjected to the Same Preparation Condition. American Journal of Food Technology, 6: 705708.

Oluyemi, E. A. ,Akinlua, A. A. , Adenuga, A.A. and Adebayo, M.B. 2006. Mineral contents of some commonly consumed Nigerian foods. Science Focus, 11 (1): 153-157.

Onibon, V. O., Abulude, F. O. and Lawal, L. O.(2007. Nutritional and antinutritional composition of some Nigerian fruits. Journal of food technology. 5 (2): 120-122.

Rutkowski M., Grzegorczyk K., 2007. Modifications of spectrophotometric methods for antioxidative vitamins determination convenient in analytic practice. Acta Sci. Pol., Technol. Aliment. 6 (3): 17-28.

S. A. S. 2002. Statview statistical package (English version 7.0) SAS incorporation, Newyork : 186-200.

Shivali, N. M. and Pradeep, K. 2009. Hibiscus sabdariffa linn. An overview journal of natural product radiance 8 (1): 77-83.

Shrawan, S., Duniya, R. S. Ashish, N. and Salim, K. M. 2013. Estimation of phytochemicals and antioxidant activity in Hibiscus sabdariffa linn. Journal of progressive Horticulture. 45 (1): 174181.

Tee, P. L., Yusuf, S. and Mohamed, S. 2002. Antioxidant properties of roselle (Hibiscus sadariffa in linoleic acid model system. Nutrition and food science: $32,17-20$

Tsai, P. J., Mclntosh, J., Pearce, P., Camden, B. and Jordan, B. R. 2002. Anthocyanin and antioxidant capacity in roselle (Hibiscus sabdariffa L.) extract. Food research international: 35, 351-356.

Umar, K.J., Hassan, L.G., Dangoggo, S.M. and Ladan, M. 2007. Nutritional Composition of Water Spinach (ipomoea aquatic Forsk) Leaves. Journal of Applied science, 7 (6): 803-809. 